Іллющенко С. Ю., ад’юнкт кафедри суспільних наук, НУОУ імені Івана Черняховського https://orcid.org/0000-0002-5963-8020

\title{
ВПЛИВ РЕФЛЕКСІЇ НА РОЗВИТОК ПРОФЕСІЙНОЇ КОМПЕТЕНТНОСТІ ОФЩЕРІВ ЗБРОЙНИХ СИЛ УКРАЇНИ
}

У статті подано теоретичний аналіз понять компетентність, рефлексія, професійна рефлексія, рефрлексивна компетентність, розглянуто історичний аспект дослідження рефлексії в психології та проведено аналіз наукової літератури з проблеми дослідження. Обтрунтовано значимість рефлексії як умови формування суб'єктивності і визначено місце рефлексивної компетентності в структурі професійної компетентності.

Ключові слова: компетентність; професійна компетентність; рефлексія; професійна рефлексія; рефлексивна компетентність.

\section{Постановка проблеми.}

Актуальність дослідження обумовлена збільшенням уваги до проблеми формування професійної рефлексії в розрізі суспільногуманітарних наук. Важливість оволодіння вміннями професійної рефлексії підкреслюється багатьма дослідниками, оскільки вона сприяе адекватній самореалізації майбутнього фахівця в професійній сфері через пізнання власних можливостей, якостей, і як наслідок, їх розвиток.

Як показує практика, сучасні умови професійної діяльності вимагають від офіщерів ЗС України вміння швидко реагувати на виникаючі завдання, приймати нестандартні рішення, передбачити наслідки прийнятих рішень.

Офіцер повинен мати не тільки достатню компетентність для вирішення професійних завдань у мирний і воєнний час, він повинен вміти швидко орієнтуватися в мінливій обстановці і адаптуватися до неї, приймати управлінські рішення.

Аналіз останніх досліджень i публікацій.

Проблемі компетентності фахівця серед вітчизняних і зарубіжних науковців приділяли увагу Г Артюшин, В. Байденко, Н. Дем'яненко, О. Дубасенюк, Г. Сльнікова, Е. Зеєр, І. Зязюн, Н. Кузьміна, Н. Ничкало, О. Овчарук, О. Пометун, Дж. Равен, В. Свистун, В. Сластьонін, А. Хуторськой, В. Ягупов та інші. У працях зазначених науковців визначається сутність компетентності фахівця, а також основні аспекти професійної компетентності.

Мета дослідження - розглянути сутність професійної рефлексії та іiі роль у професійній діяльності офіщерів ЗС України.

Методи дослідження. Оглядовоаналітичне дослідження наукових джерел.
Виклад основного матеріалу.

Для визначення професійної компетентності офіцера ЗС України, необхідно з'ясувати сутність поняття «компетентність». Враховуючи його іноземне походження, для визначення ми звернулися до словників іноземних мов, у яких компетентність тлумачиться як 1) «володіння знаннями, які дозволяють судити про щонебудь, висловлювати вагому, авторитетну думку» [23, 315]; 2) «поінформованість, обізнаність, авторитетність» [24, 282].

А. Хуторський поняття «компетентність» визначає, як поєднання відповідних знань i здібностей, що дозволяють обгрунтовано міркувати про сферу діяльності й ефективно в ній діяти [31, 59].

У роботах, виконаних під керівництвом Л. Петровської, компетентність розуміється як базова відповідність особистості розв'язуваним задачам, які постають перед нею у процесі діяльності [14]. Більшість авторів, посилаючись на В. Дьоміна, визначають компетентність як «рівень умінь особистості, що відображає ступінь відповідності визначеної компетенції та дозволяе діяти конструктивно в мінливих соціальних умовах» [6].

На думку відомих українських науковців (Л. Долинська, О. Лозова, С. Максименко) компетентність необхідна для того, щоб забезпечити процес використання отриманих у досвіді знань та вмінь для вирішення певних проблем [4], [10], [11].

В роботах іноземних дослідників поняття «компетентність» часто визначається через поняття «здатність». Так Т. Холенд пов'язує компетентність зі здатністю особистості виконувати специфічну діяльність за визначеним стандартом [37]. Р. Боятцис компетентність прирівнюе до здатності 


\section{Питання психології}

використовувати наявні знання та вміння в нових ситуаціях професійного життя. Ці здатності стосуються не тільки виконання, але й планування та організації всієї діяльності [34]. Досить лаконічне визначення поняттю «компетентність» дає Дж. Бурджоні 3 колегами, визначаючи іiі як здатність i бажання виконувати завдання [35], а М. Малдер - як здатність домагатися певних досягнень у діяльності [38] А. Фурнхем спробував дати узагальнююче визначення, пов'язавши компетентність із фундаментальними здібностями та вміннями, необхідними для успішної роботи [36].

Аналіз існуючих визначень поняття «компетентність» привів нас до розуміння компетентності як цілісної інтегральної характеристики, сукупності компетенцій, заснованих на знанні і придбаному досвіді, яка проявляється в практичній діяльності в єдності з особистими якостями.

Важливим для нас $\epsilon$ визначення поняття «професійна компетентність» та «військовопрофесійна компетентність» щодо офіцера збройних сил. Аналіз наукових досліджень 3 цієї проблеми дозволив нам прийти до висновку, що перші системні дослідження професійної компетентності військових розпочали зарубіжні вчені. Так, Самуел П. Хантінгтон у роботі «Солдат і держава» досліджуе проблему військового професіоналізму, розкриває сутність та зміст цього феномена через єдність таких компонентів, як компетентність, відповідальність, відданість власній справі. Компетентність автор розглядає як складову професіоналізму, відмінну рису професіонала від звичайного виконавця $[8,18]$.

С. Саркесьян, аналізуючи компетентність у сфері забезпечення безпеки країни, визначає iii як широту мислення, не обмежену військовими міркуваннями, що дозволяе враховувати соціальні та політичні наслідки військових рішень, i вірно розуміти необхідність первинного рішення питань $[8$, $18]$.

Карл Е. Вуоно, генерал армії США, визначає сутність професійної компетентності як досконале знання власної справи. Поняття професіонала на особистісному рівні він визначає як керівника, який $є$ професійним військовим спеціалістом, несе відповідальність за солдат та підрозділи, має обов'язки щодо захисту нації та суворо дотримується етичних норм $[8,18]$.

Відтак, зарубіжні дослідники вважають: професійна компетентність формується здебільшого внаслідок практичної діяльності та професійного самовдосконалення.

Для успішного здійснення військової діяльності, на сьогоднішній день необхідним $\epsilon$ наявність у офіцера сформованої професійної компетентності, як здатності до ефективного вирішення завдань що виникають в ході здійснення військової служби.

Б. Тухватуллін в своєму дисертаційному дослідженні зазначає: «Військово-професійна компетентність - інтегративна якість майбутніх офіцерів, що являє собою сукупність професійно значущих якостей, здатність і готовність вирішувати професійні проблеми i завдання, які виникають в службово-бойовій діяльності, 3 використанням знань, навичок, умінь, утворених системою ключових компетентностей, що складаються в процесі навчання і розвиваються в діяльності» [29].

О. Караяні так визначає професійну компетентність офіцера: «Професійна компетентність офіцера-вихователя - це певний рівень знань, навичок i умінь, що дозволяе йому самостійно виконувати професійні обов'язки, забезпечуючи відповідність процесуальної та результативної сторін діяльності нормативним вимогам» [7, 5].

На думку О. Антонова, Л. Маслак професійна компетентність офіцера радіоінженерної спеціальності має такі компоненти:

- Концептуальний (військове-професійні знання);

- Інструментальний (професійні уміння та навички);

- Інтегративний (поєднання теорії та практики при вирішенні професійних проблем);

- Контекстуальний (розуміння соціального та культурного середовища, у якому здійснюється професійна діяльність);

- Комунікативний (стиль спілкування, уміння ефективно використовувати письмові та усні засоби спілкування) $[16,154]$.

Є. Бударін, використовуючи комплексний підхід, визначає такі структурні компоненти професійної компетентності військового спеціаліста зв'язку:

- професійний досвід;

- уміння системно сприймати професійну реальність;

- здібність вільно орієнтуватися в

предметній області;

- технологічність;

- уміння інтегруватися 3 «іншим» досвідом; 


\section{Питання психології}

- креативність;

- здатність до рефлексії.

Цей автор наголошує, що перераховані компоненти професійної компетентності можна розглядати як тісно взаємопов'язані i нормативно необхідні для успішної діяльності спеціаліста в сучасних умовах [2, 7-81.

Дослідження, присвячені професійній компетентності, все більше апелюють до рефлексії, розглядаючи іiі i як змістовний елемент, і як умову ऑii розвитку $[5,59]$. Рефлексією регулюються усі компоненти професійної компетентності. Завдяки рефлексії особистістю фіксуються цілі, процес і результат своєї професійної діяльності, а також усвідомлення тих внутрішніх змін, які в ній відбуваються, усвідомлення себе як особистості, що змінюється. Хочемо зазначити, що одним із структурних компонентів військово-професійної компетентності офіцера ЗС України $\epsilon$ рефлексивні вміння, які полягають у здійсненні самостійного збору, аналізу, обробки та інтерпретації необхідної інформації, придбання й інтегрування нових знань шляхом самоосвіти, вміння всебічно оцінювати обстановку будь-якого рівня складності (виділяти найбільш актуальні фактори і проблеми, в т.ч. в умовах неповної або обмеженої інформації, в новому або незнайомому середовищі), впевнено приймати обгрунтовані рішення (передбачити наслідки і нести особисту відповідальність за ïx прийняття), організовувати i практично втілювати рішення в життя (досягати поставлених цілей у мирний і воєнний час) на основі глибоких знань можливостей, форм i способів застосування своїх сил та засобів $\mathrm{i}$ противника.

Основне підгрунтя для виокремлення рефлексивної компетентності військового спеціаліста ми знайшли у дослідженні В. Ягупова [33], де аргументовано доведено, що офіцер, який веде активну військову діяльність, повинен уміти обмірковувати та проектувати свої дії, прогнозувати результати, оцінювати досягнуте, зіставляючи результат із поставленою перед собою метою. Саме цим ми керувалися, обравши рефлексивну компетентність як важливий компонент у структурі професійної компетентності офіцера ЗС України

Традиційно рефлексивну компетентність розглядали як важливий компонент професійної компетентності або професійної діяльності [21, 77]. Проте мало хто 3 дослідників вивчав рефлексивну компетентність як самостійне утворення психіки, що визначає результативний аспект рефлексивної активності.

У другій половині $\mathrm{XX}$ століття виокремилися декілька підходів до вивчення рефлексивної компетентності особистості: як складової професійної компетентності особистості (М. Головань, А. Деркач, В. Зазикін, Н. Кузьміна, А. Маркова, 3. Сейдаметова та ін.); як рівня організації професійної компетентності (Д. Бауме, Е. Тейлор, В. Ховел, А. Чепмен, Дж. Чиверс, Г. Чизем, Д. Шон та ін.); як професійно важливої якості, що позитивно впливає на процеси індивідуально-професійного розвитку (І. Войтик, О. Гулєєва, І. Єліна, В. Зданюк, Л. Калініна, Ю. Кушеверська, I. Остапенко, О. Поліщук, Г. Полякова та I. Стеценко, В. Раскалінос, С. Степанов, I. Семенов, I. Ульяніч, Т. Яркіна та ін.); як метакомпетентності, що визначають продуктивність будь-якої форми діяльності (Ю. Бабаян, А. Деркач, В. Желанова, В. Метаєва, К. Нор, І. Ульяніч та ін.).

Так О. Поліщук визначила рефлексивну компетентність як «професійну якість особистості, що дозволяє найбільш ефективно і адекватно здійснювати рефлексивні процеси, реалізацію рефлексивної здатності, що забезпечує процес розвитку і саморозвитку, сприяє творчому підходу до професійної діяльності, досягненню іiі максимальної ефективності та результативності» $[18,30]$. Дане поняття, на думку дослідниці, повинно зайняти своє місце в низці вже розроблених понять, таких як «рефлексія», «рефлексивність», «рефлексивна готовність», «рефлексивна культура» та ін. Таке визначення $є$ найбільш універсальним, тому його використовують більшість дослідників. Схоже визначення рефлексивній компетентності надала i В.Раскалінос, визначаючи іiі як обізнаність фахівця щодо «процесів актуалізації особистості, реалізації рефлексивних здібностей в осмисленні й подоланні стереотипів мислення й утворенні нового інноваційного змісту» $[17,179]$.

I. Єліна визначає два напрями аналізу діяльності, які забезпечуються структурами рефлексивної компетентності: за змістом та за способом реалізації. Тому головною функцією рефлексивної компетентності, є усвідомлення свого визнання та засобів його реалізації, а також ретельний аналіз результатів своєї діяльності 3 метою визначення їхньої соціальної цінності $[9,311]$.

М. Лук'янова розглядає рефлексивну компетентність у структурі рефлексивної культури, як обширне інтегративне утворення. 


\section{Питання психології}

За підходом В. Сластеніна, рефлексивна культура $\epsilon$ системотворчим фактором професіоналізму, що включає сукупність здібностей, способів і стратегій, які забезпечують усвідомлення i подолання стереотипів особистісного досвіду, переосмислення та подолання проблемних ситуацій, що виникають у процесі розв'язання професійних задач [22].

О. Савченко у своїх працях розглядає рефлексивну компетентність як інтегративне утворення, що формується в процесі рефлексивного досвіду особистості та забезпечує високу продуктивність реалізації рефлексивності як загальної здібності за рахунок переведення потенційних форм в актуальні результати та досягнення [20].

С. Михєєв розглядає рефлексивну компетентність як важливу складову загальної професійної компетентності (разом із самооцінкою, аутопсихологічною компетентністю та здатністю до саморегулювання) управлінців. Дослідник розмежовує рефлексивну та аутопсихологічну компетентності як різні форми. Під «рефлексивною компетентністю» в більшій мірі розуміється здатність до самоаналізу та переосмислення своєї діяльності, адекватної самооцінки рівня розвитку своїх здібностей. Аутопсихологічна компетентність розглядається автором як «здатність здійснювати продуктивне самопізнання, самооцінку, самодіагностику, що дозволяє ефективно i довільно здійснювати саморегуляцію, позитивно направляти процеси самомотивації, i, насамкінець, саморозвитку» [12].

Рефлексивна компетентність - це професійна якість професіонала, що полягає передусім в обізнаності фахівця щодо процесів актуалізації особистості, реалізації рефлексивних здібностей в осмисленні й подоланні стереотипів мислення й утворенні нового інноваційного змісту. Особливо велика роль рефлексивної компетентності у переосмисленні особистісного та професійного досвіду, що сприяє формуванню нових професійних еталонів i стандартів, які стимулюють розвиток. Рефлексивна компетентність, за визначенням С. Степанова, - це «професійна якість особистості, яка дозволяє ефективно та адекватно здійснювати рефлексивні процеси, реалізацію рефлексивної здатності, що забезпечує розвиток і саморозвиток, сприяє творчому підходу в професійній діяльності, досягненню іiі максимальної ефективності та результативності» $[28,266]$.
На підставі аналізу існуючих визначень поняття «рефлексивна компетентність» Г. Полякова запропонувала визначати іiі як інтегративну властивість особистості, що характеризується ступенем засвоєння рефлексивних компетенцій (як визначених вимог до діяльності), що включає готовність та здатність людини використовувати знання, вміння, навички, професійний та життєвий досвід [15].

Українські дослідниці Ю. Бабаян та К. Нор запропонували досліджувати рефлексивну компетентність як метаутворення, яке виступає «одним із ключових чинників особистісного та професійного розвитку в різних сферах людської діяльності», визначає ефективність розвитку всіх інших видів компетентності [1, 24].

Співвідносячи

рефлексивну компетентність 3 іншими видами, що досліджуються в психології, неможливо не погодитись 3 А. Деркачем, який відзначає, що вона являє собою метапоняття, тобто метакомпетентність, що за допомогою механізму рефлексії забезпечує своєчасне коректування й адекватний розвиток всіх інших видів компетентності [3, 681].

Саме завдяки розвитку рефлексії, як зазначає С. Михєєв, людина отримує можливість «перевести практичні обмеження в самоосвітню задачу і спланувати логіку самостійних дій відповідно до неї» $[12,52]$. I. Ульяніч вважає, що основною функцією рефлексивної компетентності $\epsilon$ переосмислення професійного й особистісного досвіду, яке здійснюється за рахунок формування особистістю власних еталонів та стандартів, які стимулюють процеси їі розвитку [30, 50].

Узагальнення результатів аналізу досліджень вищезгаданих авторів дозволило нам визначити рефлексивну компетентність офіцера ЗС України як якість, яка дозволяє найбільш ефективно і адекватно здійснювати рефлексивні процеси, актуалізуючи розвиток і саморозвиток офіщера ЗС України, сприяючи творчому підходу до професійної діяльності, досягнення іiі максимальної ефективності та результативності.

У психологічній науці склалося неоднозначне ставлення до розробки проблем рефлексії. Одні психологічні школи повністю заперечували необхідність дослідження даного феномена (біхевіоризм), інші визнавали iі основним психологічним методом [18, 79]. 


\section{Питання психології}

Поступово рефлексія завоювала місце в категоріальному i методичному апараті наукової психології. Першим привернув увагу психологів до проблем рефлексії Д. Дьюї. Психолог розумів рефлексію як паузу в судженні для подальшого дослідження, що дозволяє підтвердити або спростувати думку або ідею, що прийшла.

У 1930-х pp. А. Буземан пропонував виділити проблеми рефлексії в окрему галузь психології, що вивчає рефлексивні процеси i свідомість. Вчений сформулював визначення в психологічному руслі: рефлексія перенесення на себе хвилювання 3 зовнішнього світу [19, 223].

У психології когнітивізма розробляються поняття метапам'яті (пам'ять про власну пам'ять) і метамислення (процеси регуляції мислення), що $\epsilon$ по суті рефлексивними феноменами. Дослідження в цій галузі призвели до появи нового напряму метакогнітивізма. Даний напрямок психології досліджує механізми інтелектуальної діяльності і бере свій початок в працях Дж. Флейвелла.

Загальний сенс розуміння феномену рефлексії виражений у визначенні П. Дорнера, який описує рефлексію як здатність думати про власне мислення 3 метою його вдосконалення.

Таким чином, в зарубіжній психології простежуються два напрямки вивчення феномена рефлексії. Перший бере свій початок від інтроспективної психології, що визнала рефлексивні процеси основними у функціонуванні психіки, а рефлексування базовим методом дослідження свідомості. До другого напряму відноситься метакогнітивізм, який розглядає розвиток принципів когнітивної психології і досліджує процеси, що регулюють переробку інформації метапроцеси [8, 23].

Найбільш розгорнута класифікація рефлексивних процесів і феноменів, що враховує більшість основних підходів до їх вивчення, була запропонована С. Степановим i I. Семеновим. Намагаючись подолати звуження поняття «рефлексія», автори узагальнили основні психологічні трактування рефлексії, наведені в роботах А. Петровського, Л. Виготського, В. Давидова, А. Матюшкина, О. Тихомирова та інших вітчизняних психологів, показавши, що феномен рефлексії вивчається в наступних основних аспектах: комунікативному, кооперативному, особистісному,
Як зазначає I. Семенов, в даний час, крім поглиблення традиційної проблематики вивчення рефлексії, відбувається взаємодія психології рефлексії на базі міждисциплінарних досліджень 3 психолінгвістіки (Р. Фрумкіна), психосемантики (В. Столін), етнографією (М. Муканов, П. Тульвісте), соціологією і цілим рядом філософських дисциплін (Д. Дубровський, В. Зінченко, В. Лекторский, О. Спіркін і ін.) [27, 98].

На сучасному етапі дослідження рефлексії проводяться в рамках більшості галузей психологічного знання: рефлексивні процеси вивчаються в соціальній психології в зв'язку 3 проблемами групової взаємодії, міжособистісного спілкування, соціальної перцепції, емпатії; в загальній психології в рамках проблем самосвідомості та саморозвитку особистості, регуляції пізнавальних процесів і діяльності; здібностей і довільної активності; у віковій психології в плані їх генезису і способів формування, а також в медичній, педагогічній, організаційної психології та психології управління.

Для оцінки теперішньої ситуації в галузі вивчення рефлексії та аналізу рефлексивних процесів все ще зберігає, на жаль, свою актуальність судження Г. Щедровицького, який охарактеризував іï як ситуацію істотної девальвації поняття рефлексії «Це обумовлено, перш за все, його широким розподілом в сферах, що не мають безпосередньої практики рефлектування» $[32,139]$.

\section{Висновок.}

Проблема рефлексії $є$ однією 3 найважливіших міждисциплінарних проблем, що розробляються в рамках цілого ряду гуманітарних дисциплін: філософії, психологіï, педагогіки, соціології, культурології. Для сучасної психології категорія рефлексії $є$ однією з базових. Без аналізу рефлексивних процесів неможливо повне розуміння таких основоположних феноменів людської психіки як самосвідомість, теоретичне мислення, творчість.

Відзначаючи різноманіття розглянутих досліджень, слід визнати, що у військовій психології проблема впливу рефлексії на становлення професійної компетентності офіцера ЗС України недостатньо розроблена. Мало хто 3 дослідників вивчав рефлексивну компетентність як самостійне утворення психіки, що визначає результативний аспект рефлексивної активності.

Щоб відповідати сучасним вимогам життя і професії, офіщер ЗС України повинен 


\section{Питання психології}

удосконалюватися в інтелектуальному, моральному, комунікативному і емоційному напрямках. Механізмом цього вдосконалення $\epsilon$ професійна рефлексія, що сприяє творчому підходу до військово-професійної діяльності, досягнення іiі максимальної ефективності та результативності. Саме рефлексія пробуджує особистісні та професійні помисли військовослужбовців усіх категорій. Рефлексуючий командир сприяє військовому колективу вийти на якісно новий рівень військово-професійної діяльності. Рефлексія допомагає військовослужбовцям відчувати незадоволеність, а отже, і міркувати про свій професійний розвиток.

Офіцер ЗС України, як професіонал, повинен приділяти належну увагу проведенню процедури самоаналізу, що безпосередньо залежить від розвинутого уміння займати рефлексивну позицію. У цілому, рефлексія виявляється в адекватних оцінках різноманітних аспектів власної професійної діяльності, власної поведінки 3 метою розв'язання професійних завдань. Рефлексія спрямована на розвиток у офіцерів ЗС України таких якостей характеру, як креативність, ініціативність, винахідливість, сміливість у прийнятті рішень, впевненість у собі, а також можливість, при необхідності, здійснити нестандартний вчинок та нести за нього усю відповідальність.

Можемо констатувати, що офіцер, який веде активну військову діяльність, повинен уміти обмірковувати та проектувати свої дії, прогнозувати результати, оцінювати досягнуте, зіставляючи результат із поставленою перед собою метою.

\section{Список використаних джерел}

1. Бабаян Ю.О., Нор К.Ф. Структура рефлексивної компетентності викладача вищої школи. Наук. вісник Миколаївського начіонального університету імені В. О. Сухомлинського. Миколаїв, 2014. № 2.13. C. $22-26$.

2. Бударин Е.А. Формирование профессионального опыта специалиста связи у курсантов военноучебных заведений: автореф. дис. ... канд. пед. наук : 13.00.08. Калининград, 2006. 20 с.

3. Деркач А.А. Акмеологические основы развития профессионала : Москва : МПИ, 2004. 752 с.

4. Долинська Л.В. Особистості першого самовизначення студентів педвузу подвійних спеціальностей. зб. наук. пращь НПУ ім. М.П. Драгоманова. Київ, 2000. №. 2 (9). Ч.ІІ. С. 148-155.

5. Драч I.I. Управління формуванням професійної компетентності магістрантів педагогіки вищої школи : монографія. Київ, 2013. 456 с.

6. Дубасенюк О.А. Особенности профессионального становления учителя в контексте компетентностного подхода. Вектор науки Тольяттинского государственного университета. 2010. № 2 (2). C. 38-42. URL: http://eprints.zu.edu.ua.

7. Караяни А.Г. Сыромятников И.В. Введение в профессию военного психолога : учеб. пособ. Москва, 2007. 208 с.

8. Коленко Ю. В. Использование информационных технологий как средства формирования профессиональной компетентности курсантов военных вузов: дис. ... канд. пед. наук: 13.00.08. Ставрополь, 2005. 210 с.

9. Кушеверская Ю. В. Рефлексивная компетентность как необходимое условие подготовки студентов к профессиональной педагогической деятельности. Известия Российского государственного педагогического университета им. А.И. Гериена. 2007. Том 39. № 39. С. 310-315.

10. Лозова О. М. Компетентнісний підхід у професійній підготовці майбутніх психологів : монографія / за ред. О. М. Лозової. Вінниця, 2014. С. 5-11.

11. Максименко С.Д. До проблеми розробки освітньо-кваліфікаційної характеристики сучасного психолога. Наук.-практ. та освіт.-метод. журн. Ін-та психологї ім. Г.С. Костюка АПН України. 1999. № 1. C. 2-6.

12. Михеев С.С. Акмеологические факторы, обеспечивающие эффективное развитие управленческой компетентности госслужащих. Информационный гуманитарный портал «Знание. Понимание, Умение». Педагогика. Психология. 2010. № 2. URL: http://www.zpu-journal.ru/ezpu/2010/2/Mikheev.

13. Моляко В.А. Психология конструкторской деятельности : Москва, 1983. 134 с.

14. Петровская Л.А. Компетентность в общении: социально-психологический тренинг : Москва : МГУ, $1982.216 \mathrm{c.}$

15. Полякова Г.А. К вопросу формирования рефлексивной компетентности студентов педагогических ВУЗов. Эмиссия. Оффлайн: научно-педагогический интернет-журнал. 2011. URL: http://www.emissia.org/ offline /2011/1615.htm.

16. Професійна педагогічна освіта: компетентнісний підхід: монографія / за ред. О.А. Дубасенюк. Житомир : ЖДУ, 2011. 412c.

17. Раскалінос В.М. Рефлексивна компетентність як складова професійної характеристики майбутнього фахівця. зб. наук. праць Уманського державного педагогічного університету імені Павла Тичини. Умань, 2011. № 4. Ч. 1. С. 176-182 


\section{Питання психології}

18. Растянников А.В. Рефлексивное развитие компетентности в совместном творчестве : Москва, 2002. $320 \mathrm{c}$.

19. Розин В.М. Рефлексия в структуре сознания личности : Новосибирск, 1987. С. 222-228.

20. Савченко О.В. Особливості функціонування рефлексивної компетентності як цілісної системи. Психологічні перспективи. № 27, 2016. С 226-227.

21. Савченко О.В. Психологія рефлексивної компетентності особистості : дис. ... докт. псих. наук : 19.00.01. Луцьк, 2016. 658 с.

22. Сластенин В.А. Рефлексивная культура и профессионализм учителя. Педагогическое образование и наука. 2005. № 3. С. 37-43

23. Словарь иностранных слов / под ред. И.В. Лехина, С.М. Локшиной, Ф. Н. Петрова. Москва : Из-во Сов. энциклопедия, 1964. 784 с.

24. Словник іншомовних слів / уклад. С. М. Морозов, Л. М. Шкарапута. Київ : Наукова думка, $2000.680 \mathrm{c}$.

25. Семенов И.Н. Взаимодействие отечественной и зарубежной психологии рефлексии: история и современность. Журнал Высшей школы экономики. 2008. Т. 5. № 1. С. $64-76$.

26. Степанов С.Ю. Психология рефлексии: проблемы и исследования. Вопросы психологии. 1985. № 3. C. $31-40$

27. Степанов С.Ю., Семенов И.Н. Проблема формирования типов рефлексии в решении творческих задач. Вопросы психологии. 1982. № 1. С. 99-104

28. Степанов С.Ю. Рефлексивная компетентность как базовая категория пердпринимательской деятельности. Новосибирск. НГУ, 1995. С. 266-271.

29. Тухватуллин Б.Т. Педагогические условия формирования военно-профессиональной компетентности курсантов вузов внутренних войск МВД России: дис. ... канд. пед. наук: 13.00.08. Махачкала, 2013. $181 \mathrm{c.}$

30. Ульяніч І.В. Рефлексивна компетентність у педагогічній діяльності. Практична психологія та соціальна робота. Київ, 2009. № 2. С. 49-51.

31. Хуторский А.В. Ключевые компетенции как компонент личностно-ориентированой парадигмы образования. Народное образование. Москва, 2003. № 2. С. 58-64

32. Щедровицкий Г.П. Коммуникация, деятельность, рефлексия. Алма-Ата, 1979. С. 138-154

33. Ягупов, В.В. Теорія і методика військового навчання: монографія. Київ, 2000. 380 с.

34. Boyatzis R. E. The Competent Manager: A model for effective performance / R. E. Boyatzis. - NY. : John Wiley \& Sons, 1982. 382 p.

35. Burgoyne J. G. Valuing leadership development: A practices \& challenge approach / J. G. Burgoyne, M. Pedler // Organisations \& People. - 2005. - Vol. 12, № 1. - P. 49-68.

36. Furnham A. Correlates of self-rated business competencies [An internet resource] / A. Furnham, A. Mansi // International Journal of Business and Management. - 2011. - Vol. 6, № 9. - URL: http://ccsenet.org/journal/ index.php/ijbm/article/viewFile/9799/8395.

37. Hyland T. Competence, knowledge and education / T. Hyland // Journal of Philosophy of Education. 1993. Vol. 27, № 1. P. 57-68.

38. Mulder M. Competence development in public and private organisations: A survey of its use in practice in selected EU member states [An internet resource] /M. Mulder, K. Collins. - URL: http://www.mmulder.nl/wp-content/uploads/201 1/12/2007-09-19-Competence-Development-in-P-andPOrganisations.pdf.

\section{References}

1. Babaian Yu.O., Nor K.F. Struktura refleksyvnoi kompetentnosti vykladacha vyshchoi shkoly. Nauk. visnyk Mykolaivskoho natsionalnoho universytetu imeni V. O. Sukhomlynskoho. Mykolaiv, 2014. № 2.13. S. 22-26.

2. Budaryn E.A. Formyrovanye professyonalnoho opыta spetsyalysta sviazy u kursantov voennouchebnukh zavedenyi: avtoref. dys. ... kand. ped. nauk : 13.00.08. Kalynynhrad, 2006. $20 \mathrm{~s}$.

3. Derkach A.A. Akmeolohycheskye osnovы razvytyia professyonala : Moskva : MPY, 2004. $752 \mathrm{~s}$.

4. Dolynska L.V. Osobystosti pershoho samovyznachennia studentiv pedvuzu podviinykh spetsialnostei. zb. nauk. prats NPU im. M.P. Drahomanova. Kyiv, 2000. №. 2 (9). Ch.II. S. 148-155.

5. Drach I.I. Upravlinnia formuvanniam profesiinoi kompetentnosti mahistrantiv pedahohiky vyshchoi shkoly : monohrafiia. Kyiv, 2013. $456 \mathrm{~s}$.

6. Dubaseniuk O.A. Osobennosty professyonalnoho stanovlenyia uchytelia v kontekste kompetentnostnoho podkhoda. Vektor nauky Toliattynskoho hosudarstvennoho unyversyteta. Seryia: Pedahohyka, psykholohyia. 2010. № 2 (2). S. 38-42. URL: http://eprints.zu.edu.ua.

7. Karaiany A.H. Stromiatnykov Y.V. Vvedenye v professyiu voennoho psykholoha : ucheb. posob. Moskva, 2007. $208 \mathrm{~s}$.

8. Kolenko Yu. V. Yspolzovanye ynformatsyonnыkh tekhnolohyi kak sredstva formyrovanyia professyonalnoi kompetentnosty kursantov voennukh vuzov: dyss. kand. ped. nauk: 13.00.08 / Kolenko Yuryi Vladymyrovych. Stavropol, 2005. $210 \mathrm{~s}$. 


\section{Питання психології}

9. Kusheverskaia Yu. V. Refleksyvnaia kompetentnost kak neobkhodymoe uslovye podhotovky studentov k professyonalnoi pedahohycheskoi deiatelnosty. Yzvestyia Rossyiskoho hosudarstvennoho pedahohycheskoho unyversyteta ym. A. Y. Hertsena. 2007. Tom 39. № 39. S. 310-315.

10. Lozova O. M. Kompetentnisnyi pidkhid u profesiinii pidhotovtsi maibutnikh psykholohiv : monohrafiia / za red. O. M. Lozovoi. Vinnytsia, 2014. S. 5-11.

11. Maksymenko S.D. Do problemy rozrobky osvitno-kvalifikatsiinoi kharakterystyky suchasnoho psykholoha. Nauk.-prakt. ta osvit.-metod. zhurn. In-t psykholohii im. H.S. Kostiuka APN Ukrainy. 1999. № 1. S. 2-6.

12. Mykheev S.S. Akmeolohycheskye faktorb, obespechyvaiushchye эffektyvnoe razvytye upravlencheskoi kompetentnosty hossluzhashchykh. Ynformatsyonnыi humanytarnыi portal «Znanye. Ponymanye, Umenye». Pedahohyka. Psykholohyia. 2010. № 2. URL: http://www.zpu-journal.ru/e-zpu/2010/2/Mikheev.

13. Moliako V.A. Psykholohyia konstruktorskoi deiatelnosty : Moskva, 1983. $134 \mathrm{s.}$

14. Petrovskaia L.A. Kompetentnost v obshchenyy: sotsyalno-psykholohycheskyi trenynh : Moskva : MHU, 1982.216s.

15. Poliakova H.A. K voprosu formyrovanyia refleksyvnoi kompetentnosty studentov pedahohycheskykh VUZov. Эmyssyia. Offlain: nauchno-pedahohycheskyi ynternet-zhurnal. 2011. URL: http://www.emissia.org/ offline $/ 2011 / 1615 . h t m$.

16. Profesiina pedahohichna osvita: kompetentnisnyi pidkhid: monohrafiia / za red. O.A. Dubaseniuk. Zhytomyr : ZhDU, 2011. 412s.

17. Raskalinos V.M. Refleksyvna kompetentnist yak skladova profesiinoi kharakterystyky maibutnoho fakhivtsia. zb. nauk. prats Umanskoho derzhavnoho pedahohichnoho universytetu imeni Pavla Tychyny. Uman, 2011. № 4. Ch. 1. S. 176-182

18. Rastiannykov A.V. Refleksyvnoe razvytye kompetentnosty v sovmestnom tvorchestve : Moskva, 2002. $320 \mathrm{~s}$.

19. Rozyn V.M. Refleksyia v strukture soznanyia lychnosty : Novosybyrsk, 1987. S. 222-228.

20. Savchenko O.V. Osoblyvosti funktsionuvannia refleksyvnoi kompetentnosti yak tsilisnoi systemy. Psykholohichni perspektyvy. № 27, 2016. S 226-227.

21. Savchenko O.V. Psykholohiia refleksyvnoi kompetentnosti osobystosti : dys. ... dokt. psykh. nauk : 19.00.01. Lutsk, 2016. $658 \mathrm{~s}$.

22. Slastenyn V.A. Refleksyvnaia kultura y professyonalyzm uchytelia. Pedahohycheskoe obrazovanye y nauka. 2005. № 3. S. 37-43

23. Slovar ynostrannыkh slov / pod red. Y.V. Lekhyna, S.M. Lokshynoi, F. N. Petrova. Moskva : Yz-vo Sov. эntsyklopedyia, 1964. $784 \mathrm{~s}$.

24. Slovnyk inshomovnykh sliv / uklad. S. M. Morozov, L. M. Shkaraputa. Kyiv : Naukova dumka, 2000. 680 s.

25. Semenov Y.N. Vzaymodeistvye otechestvennoi y zarubezhnoi psykholohyy refleksyy: ystoryia y sovremennost. Zhurnal Vыsshei shkolы эkonomyky. 2008. T. 5. № 1. S. $64-76$.

26. Stepanov S.Iu. Psykholohyia refleksyy: problemы y yssledovanyia. Voprosы psykholohyy. 1985. № 3. S. 31-40

27. Stepanov S.Iu., Semenov Y.N. Problema formyrovanyia typov refleksyy v reshenyy tvorcheskykh zadach. Voprost psykholohyy. 1982. № 1. S. 99-104

28. Stepanov S.Iu. Refleksyvnaia kompetentnost kak bazovaia katehoryia perdprynymatelskoi deiatelnosty. Novosybyrsk. NHU, 1995. S. 266-271.

29. Tukhvatullyn B.T. Pedahohycheskye uslovyia formyrovanyia voenno-professyonalnoi kompetentnosty kursantov vuzov vnutrennykh voisk MVD Rossyy: dys. ... kand. ped. nauk: 13.00.08. Makhachkala, 2013. $181 \mathrm{~s}$.

30. Ulianich I.V. Refleksyvna kompetentnist u pedahohichnii diialnosti. Praktychna psykholohiia ta sotsialna robota. Kyiv, 2009. № 2. S. 49-51.

31. Khutorskyi A.V. Kliuchevыe kompetentsyy kak komponent lychnostno-oryentyrovanoi paradyhmы obrazovanyia. Narodnoe obrazovanye. Moskva, 2003. № 2. S. 58-64

32. Shchedrovytskyi H.P. Kommunykatsyia, deiatelnost, refleksyia. Alma-Ata, 1979. S. 138-154

33. Iahupov, V.V. Teoriia i metodyka viiskovoho navchannia: monohrafiia. Kyiv, 2000. $380 \mathrm{~s}$.

34. Boyatzis R. E. The Competent Manager: A model for effective performance/ R. E. Boyatzis. - NY. : John Wiley \& Sons, 1982. 382 r.

35. Burgoyne J. G. Valuing leadership development: A practices \& challenge approach / J. G. Burgoyne, M. Pedler // Organisations \& People. - 2005. - Vol. 12, № 1. - R. 49-68.

36. Furnham A. Correlates of self-rated business competencies [An internet resource] / A. Furnham, A. Mansi // International Journal of Business and Management. - 2011. - Vol. 6, № 9. - URL: http://ccsenet.org/journal/ index.php/ijbm/article/viewFile/9799/8395.

37. Hyland T. Competence, knowledge and education / T. Hyland // Journal of Philosophy of Education. 1993. Vol. 27, № 1. R. 57-68.

38. Mulder M. Competence development in public and private organisations: A survey of its use in practice in selected EU member states [An internet resource] /M. Mulder, K. Collins. - URL: http://www.mmulder.n1/wp-content/uploads/2011/12/2007-09-19-Competence-Development-in-P-and-

POrganisations.pdf. 


\section{Питання психології}

\section{Резюме \\ Ильющенко С., адъюнкт кафедры общественных наук НУОУ имени Ивана Черняховского \\ ВЛИЯНИЕ РЕФЛЕКСИИ НА РАЗВИТИЕ ПРОФЕССИОНАЛЬНОЙ КОМПЕТЕНТНОСТИ ОФИЦЕРОВ ВООРУЖЕННЫХ СИЛ УКРАИНЫ}

В статье представлень теоретический анализ понятий компетентность, рефлексия, профессиональная рефлексия, рефлексивная компетентность, рассмотрены исторический аспект исследования рефлексии в психологии и проведен анализ научной литературы по проблеме исследования. Обоснованно значимость рефлексии как условия формирования субъективности и определено место рефлексивной компетентности в структуре профессиональной компетентности.

Ключевые слова: компетентность; профессиональная компетентность; рефлексия; профессиональная рефлексия; рефлексивная компетентность.

\section{Summary}

Ilyushchenko S., Adjunct of the Department of Social Sciences

of Ivan Chernyakhovsky National Defense University of Ukraine

\section{THE EFFECT OF REFLECTION ON THE DEVELOPMENT OF THE PROFESSIONAL} COMPETENCE OF OFFICERS OF THE ARMED FORCES OF UKRAINE

The purpose of the study is to consider the essence of professional reflection and its role in the professional activity of officers of the Armed Forces of Ukraine.

Methods. Review and analytical study of literature.

Originaliti. Studies on professional competence are often appealing to reflection, considering it both as a meaningful element and as a condition for its development. Reflection regulates all components of professional competence. Reflection of personality captures the goals, process and result of one's professional activity, as well as an awareness of those internal changes that take place in it, an awareness of oneself as a changing personality. We would like to point out that one of the structural components of the military-professional competence of an officer of the Armed Forces of Ukraine is reflexive skills, which consist in the independent collection, analysis, processing and interpretation of necessary information, acquisition and integration of new knowledge through self-education, the ability to fully evaluate any situation level of difficulty (to identify the most relevant factors and problems, including in the context of incomplete or limited information, in a new or unfamiliar environment), confidently accept the rationale decision (expected effects and take personal responsibility for their decision), organize and implement practical solutions to life (to achieve the objectives of peace and war time) based on a deep knowledge of opportunities, forms and methods of their application capabilities and the enemy.

Conclusion. The officer of the Armed Forces of Ukraine, as a professional, should pay due attention to the procedure of self-examination, which depends directly on the developed ability to take a reflexive position. In general, reflection manifests itself in adequate assessments of various aspects of one's professional activity and one's own behavior in order to solve professional tasks. The reflection is aimed at the development of such qualities of the officers of the Armed Forces of Ukraine as creativity, initiative, ingenuity, courage in decisionmaking, self-confidence, as well as the opportunity, if necessary, to perform a non-standard act and bear all responsibility for it. It can be stated that an officer conducting active military activity should be able to think and design his actions, predict the results, evaluate the achieved, comparing the result with the set goal.

Keywords: competence; professional competence; reflection; professional reflection; reflexive competence. 